\title{
RE-OS SYSTEMATICS OF LITHOSPHERIC PERIDOTITES \& ECLOGITES FROM THE BOBBEJAAN \& BELLSBANK DYKES, KAAPVAAL CRATON, SOUTH AFRICA.
}

\author{
Benjamin P. Garden', Richard W. Carlson ${ }^{2}$, Steven B. Shirey ${ }^{2}$ and John J. Gurney ${ }^{1}$ \\ ${ }^{\prime}$ University of Cape Town, Cape Town, South Africa \\ ${ }^{2}$ Carnegie Institution of Washington, Washington D.C., USA
}

\section{INTRODUCTION:}

The age and structure of Archean lithosphere and its relationship to the overlying crust is fundamental to the understanding of how cratons form. Crustal sections of Archean crust are often composed of small blocks with distinct age related sections, which are welded together to form cratons as we see them today (eg de Wit et al, 1992). Recent developments in rhenium-osmium (ReOs) isotopic analyses make it possible to date lithospheric material, as the Re-Os system is capable in seeing through the mantle metasomatism that has plagued other isotopic systems (Carlson et al 1999). ReOs isotopic studies of Kaapvaal Craton peridotites have shown that there are broad correlations between major crust building phases and depletion events in the underlying lithosphere (Walker et al., 1989; Pearson et al., 1994, 1995, 1998; Carlson et al., 1999; Janney et al., 1999; Menzies et al., 1999; Irvine et al., 2001; Carlson \& Moore, submitted) showing a coupling effect between the crust and the lithosphere.

Previous work on the Archean crustal geology of the Kaapvaal Craton, South Africa has shown that the craton consists of a number of discrete blocks (de Wit et al, 1992). The Kaapvaal Craton in a broad sense can be split into the east and west domain, roughly defined by the Colesburg magnetic lineament (Corner et al 1990). The east domain has the best-exposed cratonic crust with the oldest crust between 3.5-3.6Ga (Carlson et al 1983, Armstrong et al 1990, Kroner et al 1993). In contrast the west domain contains poorly exposed basement with the oldest being 3.25Ga (Drennen et al 1990, Schmitz et al 2002). Deformation occurred at 2.91-2.93Ga followed by granitic magmatism between 2.85-2.88Ga (Poujol et al 2000, Schmitz et al 2002) this evidence led to the suggestion that the western Kaapvaal was accreted to the eastern Kaapvaal at 2.9Ga (Schmitz et al 2002).

To date, the most precise Re-Os mantle age for the western Kaapvaal is an isochron for eclogitic diamond inclusion sulphides at $2.89 \pm 0.06 \mathrm{Ga}$ (Richardson et al 2001). This diamond inclusion age agrees well with the average $\mathrm{T}_{\mathrm{Ma}}$ for Kimberley peridotites $(2.89 \pm 0.14$, Carlson et al 1999) but has a radiogenic initial Os isotopic composition that Richardson et al (2001) suggested was a subduction signature. Schmitz et al (2002) similarly suggested that subduction of the eastern Kaapvaal underneath the western Kaapvaal may have caused the melting and consequent Re-depletion of the mantle beneath the western Kaapvaal that is recorded in the Kimberley peridotites.

Previous Re-Os studies on Kaapvaal peridotites have focused on garnet-bearing or rare diamond-bearing peridotites and have only included a small number of samples, normally $\leq 10$ producing diverse model ages (Walker et al 1989, Pearson et al 1995, Carlson et al 1999, Menzies et al 1999, Irvine et al 2001). In an attempt to conduct a more detail study of Kaapvaal peridotites from one locality and address the potential age differences between the western and eastern Kaapvaal, xenoliths from the Bellsbank group kimberlites were chosen for Re-Os isotopic study. The Bellsbank kimberlites lie west of the Colesburg lineament. In addition to the peridotite xenoliths, seven eclogites xenoliths were also analysed to document the timing of migrating "basaltic" fluids within the craton.

\section{XENOLITH SUITE}

\subsection{XENOLITH LOCATION:}

The Bobbejaan \& Bellsbank kimberlite dykes are Group II kimberlite dykes, dated at 120Ma (Smith 1983 ) and are situated ca. $100 \mathrm{~km}$ northwest of Kimberley, South Africa. It lies west of the Colesburg lineament and thus is one of the few localities on the Western Kaapvaal block for which comprehensive ReOs data has been obtained. Collectively these parallel dykes are known as the Bellsbank group kimberlite but are approximately 1 kilometre apart.

\subsection{Peridotite Petrology:}

The lithospheric peridotites chosen for analysis are dominated by spinel peridotite with minor garnet peridotite. They contain between $30-60 \%$ olivine and $70-30 \%$ orthopyroxene (modal) and are strictly classed as spinel or garnet harzburgites. Clinopyroxene makes up $<0.5 \%$ of the rock (modal) and commonly has melted due to decompression to form blebs of glass.

Petrographically, the peridotites contain little to no clinopyroxene exsolution similar to Kimberley peridotites, and in contrast to Premier peridotites, suggesting that Bellsbank Group Kimberlite peridotites have cooled more rapidly than the Premier suite. This is also supported by the mineral chemistry with little variation in calcium, aluminium and chromium contents from rim to core in orthopyroxene grains. 
Geothermobarometry for garnet peridotites yield P/T conditions between $873-926^{\circ} \mathrm{C}$ and $40-44$ kilobars, and can be assigned to the low-temperature peridotite suite, spinel peridotites yield temperatures between 1050$850^{\circ} \mathrm{C}$. These $\mathrm{P} / \mathrm{T}$ conditions suggest that the lithosphere underneath Bellsbank lies on a 37-38 $\mathrm{mW} / \mathrm{m}^{2}$ geotherm, similar to Newlands, which is situated $30 \mathrm{~km}$ to the southeast (Menzies 1999).

There are no major element chemical or geothermobarometric differences between the Bobbejaan and Bellsbank peridotites showing a homogenous mantle sampling on the scale of ca. 1 kilometre.

\subsection{ECLOGITE PETROLOGY:}

Eclogites are dominated by garnet and clinopyroxene and can be split into three distinct groups (Shervais et al 1988). Group A, contains minor amounts of orthopyroxene, Mg-rich garnets and Cr-rich clinopyroxene, and are thought to represent mantle cumulates or crystallized komatiitic or picritic liquids. Group B, contains minor amounts of mica (primary and secondary) with Fe-rich garnets and are thought to represent basalts like modern MORB. Group C, contains minor amounts of kyanite and corundum, with Ca-rich garnet and $\mathrm{Al} \& \mathrm{Na}$-rich clinopyroxene and is thought to represent a subducted oceanic crust cumulate such as a gabbro.

\subsection{SAMPLE SELECTION:}

Twenty eight peridotites, nineteen from Bobbejaan and nine from Bellsbank were analysed for Re-Os isotopic composition along with six eclogites, four from Group $\mathrm{A}$ and two from Group B. No eclogites from group C were analysed because of concerns about kimberlite alteration in these small samples.

\section{RESULTS}

\subsection{PERIDOTITES}

All peridotitic samples analysed have Re concentrations below that of fertile mantle (0.26ppb Morgan 1986). Os concentrations vary widely, but averaged below fertile mantle (spinel peridotites $2.03 \mathrm{ppb}$, garnet peridotites $1.19 \mathrm{ppb}$ and fertile mantle 3.4ppb Morgan 1986). These Re concentrations conform to the common theory that Re behaves incompatibly during partial melting but the Os concentrations are contrary to the common belief that $\mathrm{Os}$ is compatible during partial melting. One potential explanation is that the sample is not representative because of small size $(<3 \mathrm{~cm}$ maximum dimension in most cases). Re concentrations of the Bellsbank suite are the lowest of any location yet known from the Kaapvaal Craton. Bellsbank Os concentrations are at the low end of the spectrum on the Craton scale (Figure 1). All samples have ${ }^{187} \mathrm{Re} /{ }^{188} \mathrm{Os}$ and ${ }^{187} \mathrm{Os} /{ }^{188}$ Os ratios lower than fertile mantle values
(0.42 \& 0.1287 respectively, Meisel et al 1996) indicative of long-term depletion in $\mathrm{Re}$ compared to fertile mantle, a trait shared with most Kaapvaal peridotites.

Calculated Re depletion ages $\left(\mathrm{T}_{\mathrm{RD}}\right.$, Walker et al 1989) for Bellsbank samples range from 1.96 - 3.40 Ga. Using measured $\mathrm{Re} / \mathrm{Os}$ ratios of the samples, the Re-Os mantle age model ages $\left(\mathrm{T}_{\mathrm{MA}}\right)$ range from $1.09-12.81$ $\mathrm{Ga}$. The majority of the Bellsbank samples overlap the peak of $\mathrm{T}_{\mathrm{RD}}$ and $\mathrm{T}_{\mathrm{MA}}$ model ages for Kaapvaal peridotites with only a few outliers caused by $\mathrm{Re}$ addition or contamination.

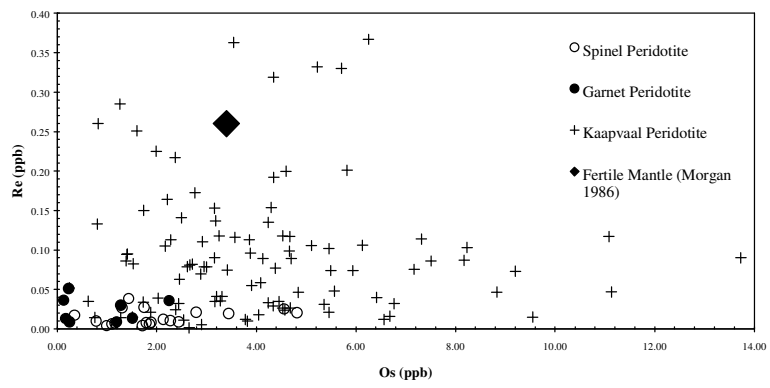

Figure 1: Re vs Os concentrations (ppb) for Bellsbank and Kaapvaal peridotites. Note the extremely low Re concentrations of the Bellsbank suite.

\subsection{ECLOGITES}

$\mathrm{Re}$ and Os concentrations of the eclogite suite vary widely from 0.005 to $0.13 \mathrm{ppb}$ and 0.015 to $0.14 \mathrm{ppb}$ respectively. ${ }^{187} \mathrm{Re} /{ }^{188} \mathrm{Os}$ and ${ }^{187} \mathrm{Os} /{ }^{188} \mathrm{Os}$ range from 0.80 to 7.66 and 0.1479 to 0.7706 respectively. Re and Os concentrations and isotopic ratios overlap previously studied locations around the Kaapvaal Craton (Shirey et al 2001, Menzies et al 2003) with Re concentrations being at the lower end of the spectrum. Model ages range from negative to $5.10 \mathrm{Ga}$. The low $\mathrm{Re}$ concentrations imply that Bellsbank eclogites have experienced a complex/multistage melt history, which is also evident in their petrography. Hence the single stage melting event model ages are not representative of the true ages of these eclogites.

\section{DISCUSSION:}

\subsection{Peridotite age Systematics and GROUPINGS}

Re-Os model ages are based on several assumptions, $\mathrm{T}_{\mathrm{RD}}$ model ages assume that the sample has had all Re removed in a single depletion event and represents the minimum age of a sample. The $\mathrm{T}_{\mathrm{MA}}$ model age assumes an isotopic evolution from a "bulk mantle" reservoir and represents only an upper limit to the true age if a sample has experienced Re addition at some point in its history. This method of formulation used is described in detail in Walker et al 1989 and Carlson et al 1999. 
Model ages when plotted against depth show the extremely tight grouping of the spinel peridotites compared to the garnet peridotites (Figure 2). These averages are shown in Table 1 . Peridotites with $\mathrm{T}_{\mathrm{MA}}$ model ages greater then the earth, which reflect Re addition in the form of kimberlite contamination or mantle metasomatism, have been excluded from the averages displayed in Table 1. Isochron systematics are non-existent in Bellsbank peridotites because of their extremely low Re concentrations giving rise to low $\mathrm{Re} / \mathrm{Os}$ ratios.

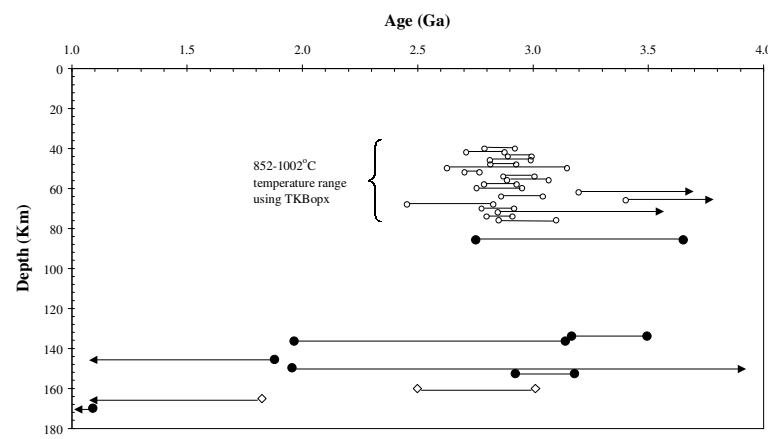

Figure 2: Age verses depth profile for Bellsbank peridotites, note the extremely tight grouping of the spinel peridotites. Open circles $=$ spinel peridotite, closed circle $=$ garnet peridotite and open diamond $=$ garnet peridotite with unknown $\mathrm{P} / \mathrm{T}$ space.

\section{Table 1: Averaged model ages for Bellsbank peridotites ${ }^{1}$}

\begin{tabular}{c|cccccc}
\hline & $\mathrm{T}_{\mathrm{RD}}$ & $2 \sigma$ & Median & $\mathrm{T}_{\mathrm{MA}}$ & $2 \sigma$ & Median \\
\hline $\begin{array}{c}\text { Spinel } \\
\text { Peridotite } \\
(15)\end{array}$ & 2.81 & 0.06 & 2.81 & 2.95 & 0.09 & 2.93 \\
$\begin{array}{c}\text { Garnet } \\
\text { Peridotite } \\
(4)\end{array}$ & 2.83 & 0.24 & 2.84 & 3.11 & 0.07 & 3.14 \\
All (19) & 2.82 & 0.10 & 2.82 & 2.98 & 0.10 & 2.97
\end{tabular}

Based on petrography and Re-Os systematics, the Bellsbank peridotites can be split into three distinctive groups: 1) Spinel Peridotite 2) Garnet Peridotite 3) Garnet Peridotite with exsolution textured garnets.

Spinel peridotites are characterised by extremely low rhenium concentrations $(0.003-0.038 \mathrm{ppb})$ with consistent model ages (averaged $\mathrm{T}_{\mathrm{RD}}=2.81 \mathrm{Ga} \pm 0.06$, $\mathrm{T}_{\mathrm{MA}}=2.95 \mathrm{Ga} \pm 0.09$ ). Garnet peridotites show more variation in rhenium and osmium concentration and model ages reflecting a higher degree of mantle metasomatism or kimberlite contamination (averaged

\footnotetext{
${ }^{1}$ Note the any sample with any signs of Re addition was left out of the both averaged model ages.
}

model ages minus extreme values, $\mathrm{T}_{\mathrm{RD}}=2.83 \mathrm{Ga} \pm$ $\left.0.24, \mathrm{~T}_{\mathrm{MA}}=3.11 \mathrm{Ga} \pm 0.07\right)$. Three garnet peridotites with exsolution textures of garnet exsolving from a single large orthopyroxene grains, show the highest rhenium and variable osmium concentrations and are characterised by negative and Proterozoic $T_{R D} \& T_{M A}$ model ages (1.09-1.88 Ga). These characteristics are thought to be caused by extreme mantle metasomatism, illustrating the complex history that these samples have experienced.

\section{IMPLICATIONS FOR WHOLE ROCK RE-OS GEOCHEMISTRY (PERIDOTITES):}

The extremely tight model ages given by the Bellsbank spinel peridotites have wider applications to Re-Os systematics for Kaapvaal peridotites and Re-Os whole rock in general and gives the first data set that population statistics can be used upon but care must be taken as some or all may be derived from the same xenolith. These unusually depleted spinel peridotites that are free of metasomatism and the Re introduced with it provide a good comparison against which to evaluate other suites with higher $\mathrm{Re} / \mathrm{Os}$ and more metasomatism and alteration.

\subsection{ECLOGITE ISOCHRON SYSTEMATICS}

On a combined isochron diagram with data from Pearson et al 1992 (Figure 3) there are two broad trends, one at $2.8 \mathrm{Ga}$ or Archean and the other at 120 Ma kimberlite eruption. No valid isochron could be fitted to the data, which suggests that some eclogites reequilibrated with, or were contaminated by, the kimberlite at time of eruption, while some retained their Archean isotopic signatures.

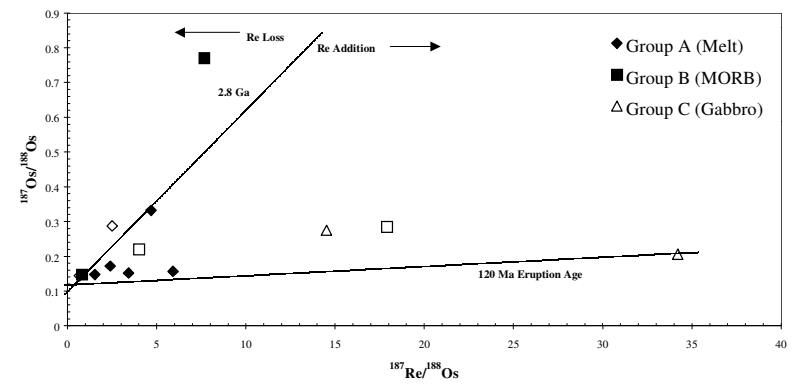

Figure 3: Bellsbank eclogite isochron diagram. This study is the filled in symbols while the open symbols are taken from Pearson et al 1992. Note the two broad trends one Archean the other Kimberlite eruption age.

\subsection{Implications for tHE KAAPVAAL CRATON}

The Bellsbank peridotites give a "Kimberley accretion" age at $\mathrm{T}_{\mathrm{RD}}=2.81 \mathrm{Ga} \pm 0.06, \mathrm{~T}_{\mathrm{MA}}=2.95 \mathrm{Ga} \pm 0.09$ (spinel peridotites are used to represent the Bellsbank lithosphere age because they show the least spread in age and Re contamination) illustrating how widespread the effects of this event was around the craton. The slightly higher $\mathrm{T}_{\mathrm{MA}}$ of $2.95 \mathrm{Ga}$ is within error of the 2.89 Ga peridotite age and eclogitic diamond inclusion 
age from Kimberley (Carlson et al 1999, Richardson et al 2001, Shirey et al., 2000, Shirey et al., 2002).

Two spinel peridotites give $\mathrm{T}_{\mathrm{RD}}$ model ages of 3.2 and $3.4 \mathrm{Ga}$ and $\mathrm{T}_{\mathrm{MA}}$ model ages greater than the earth, showing that they have experienced $\mathrm{Re}$ addition (excluded from Table 1, if included these two samples change the average $\mathrm{T}_{\mathrm{RD}}$ to $2.87 \pm 0.17$ ). If individual model ages are each to have geological significance, this suggests that there must be some lithosphere under Bellsbank between 3.2 - 3.4 Ga. This possibility suggests that the Kimberley accretion event may have overprinted an older Archean isotopic signature within the lithospheric peridotites.

If a mid-Archean age holds for Bellsbank eclogites, this illustrates that fluid movement was extensive in the lithosphere during the Archean. As Bellsbank eclogites are thought to be slab derived partial melts (Shervais et al 1988) this suggests that these eclogites are remnants of partial melts from the western domain slab as it was being subducted underneath the east domain during the Kimberley accretion event.

\section{REFERENCES}

Armstrong, R.A., Compston, W., de Wit, M.J., and Williams, I.S. (1990) The stratigraphy of the $3.5-3.2 \mathrm{Ga}$ Barberton Greenstone Belt revisited: a single zircon ion microprobe study. Earth and Planetary Science Letters 101, 90-106.

Carlson, R.W., Hunter, D.R., and Barker F. (1983) Sm-Nd age and isotopic systematics of the bimodal suite, ancient gneiss complex, Swaziland. Nature 305, 701-704, 1983.

Carlson, R. W., Pearson, D. G., Boyd, F. R., Shirey, S. B., Irvine, G., Menzies, A. H. and Gurney, J. J. (1999) Regional age variation of the southern African mantle: significance for models of lithospheric mantle formation. In: J.J. Gurney, J. L. G., M.D. Pascoe and S.H. Richardson, eds., Proceedings of the 7th International Kimberlite Conference, Red Roof Design, Cape Town, 99-108.

Carlson, R. W., Boyd, F. R., Shirey, S. B., Janney, P. E., Grove, T. L., Bowring, S. A., Schmitz, M. D., Dann, J. C., Bell, D. R., Gurney, J. J., Richardson, S. H., Tredoux, M., Menzies, A. H., Pearson, D. G., Hart, R. J., Wilson, A. H. and Moser, D. (2000) Continental growth, preservation and modification in southern Africa. GSA Today, 10, 1-7.

Corner, B., Durrheim, R.J., Nicolaysen, L.O. (1990) Relationships between the Vredefort structure and the Witwatersrand basin within the tectonic framework of the Kaapvaal craton as interpreted from regional gravity and aeromagnetic data. Tectonophysics 171, 4961.

deWit, M. J., Roering, C., Hart, R. J., Armstrong, R. A., Ronde, C. E. d., Green, R. W. E., Tredoux, M., Peberdy, E. and Hart, R. A. (1992) Formation of an Archaean continent. Nature 357, 553562.

Drennen, G.R., Robb, L.J., Meyer, F.M., Armstrong, R.A. and de Bruiyn, H. (1990) The nature of the Archaean basement in the hinterland of the Witwatersrand Basin: II. A crustal profile west of the Welkom Goldfield and comparisons with the Vredefort crustal profile. South African Journal of Geology, 93, 41-53.

Irvine, G., Pearson, D. and Carlson, R. (2001) Lithospheric mantle evolution of the Kaapvaal Craton: a ReOs isotope study of peridotite xenoliths from Lesotho kimberlites. Geophysical Research Letters, 28(13): 2505-2508.

Kroner, A., Hegner, E., Wendt, J.I., and Byerly, G.R. (1993) The oldest part of the Barberton granitoidgreenstone terrain, South Africa: evidence for crust formation between 3.5 and 3.7 Ga. Precambrian Research 78, 105-124.

Menzies, A.H., Carlson, R.W., Shirey, S.B., and Gurney, J.J. (2003) Re-Os systematics of diamond-bearing eclogites from the Newlands Kimberlite. Lithos

Menzies, A.H., Carlson, R.W., Shirey, S.B., and Gurney, J.J. (1999) Re-Os systematics of Newlands peridotites xenoliths: implications for diamond and lithosphere formation. In: J.J. Gurney, J. L. G., M.D. Pascoe and S.H. Richardson, eds., Proceedings of the 7th International Kimberlite Conference, Red Roof Design, Cape Town, 566-573.

Morgan, J.W. (1986) Ultramafic xenoliths: clues to Earth' s late accretionary history. Journal of Geophysical Research 91, 12375-12387.

Pearson, D. G. (1999) Evolution of cratonic lithospheric mantle: an isotopic perspective, in Fei, Y., Bertka, C.M. and Mysen, B.O. eds., Mantle Petrology: Field Observations and High Pressure Experimentation,: A tribute to Francis R. (Joe) Boyd, Geochemical Society Special Publication 6, 57-78.

Pearson, D. G., Shirey, S. B., Carlson, R. W., and Taylor, L. A. (1992) Os isotopes constraints on the petrogenesis of eclogite xenoliths. EOS. Trans. AGU. 73(14), Spring Meeting Suppl. 376

Pearson, D. G., Boyd, F. R., Hoal, K. E. O., Hoal, B. G., Nixon, P. H. and Rogers, N. W. (1994) A ReOs isotopic and petrological study of Namibian peridotites: contrasting petrogenesis and composition of on- and off-craton lithospheric mantle. Mineralogical Magazine 58A, 703704.

Pearson, D. G., Carlson, R. W., Shirey, S. B., Boyd, F. R. and Nixon, P. H. (1995) Stabilization of Archaean lithospheric mantle; a Re-Os isotope study of peridotite xenoliths from the Kaapvaal Craton. Earth and Planetary Science Letters 134, 341357.

Pearson, D. G., Carlson, R. W., Boyd, F. R., Shirey, S. B. and Nixon, P. H. (1998) Lithospheric mantle growth around cratons: A Re-Os isotope study of peridotite xenoliths from East Griqualand: 
Ext. Absts. 7th International Kimberlite Conference Cape Town, 658-660.

Poujol, M., Annhaeusser, C.R., and Armstrong, R.A. (2000) Episodic Archean granitoid emplacement in the Amelia-Kraaipan terrane, South Africa: new evidence from single zircon $\mathrm{U}-\mathrm{Pb}$ geochronology with implications for the age of the western Kaapvaal Craton. Information Circular 346, Economic Geology Research Unit, University of Witwatersrand, Johannesburg, 21p.

Richardson, S.H., Shirey, S.B., Harris, J.W. and Carlson, R.W. (2001) Archean subduction recorded by Re-Os isotopes in eclogitic sulfide inclusions in Kimberley diamonds. Earth and Planetary Science Letters 191(3-4): 257-266.

Schmitz, M. D. \& Bowring, S. A. (2000) The significance of $\mathrm{U}-\mathrm{Pb}$ zircon ages from lower crustal xenoliths of the southwestern margin, Kaapvaal craton, southern Africa. Chemical Geology 172, 5976.

Schmitz, M.D., Bowring, S.A., de Wit M.J. and Gartz V. (2002) Neoarchean stabilization of the western Kaapvaal Craton: implications for Witwatersrand basin subsidence and the formation of continental lithosphere.

Shervais, J. W., Taylor, L. A., Lugmair, G. W., Clayton, R. N., Mayeda, T. K., and Korotev, R. L. (1988) Early Proterozoic oceanic crust and the evolution of subcontinental mantle: eclogites and related rocks from southern Africa. GSA, 100 411-423.

Shirey, S. B., Harris, J. W., Richardson, S. H., Fouch, M, J., James, D. E, Cartigny, P., Deines, P., Viljoen, F. (2002) Diamond Genesis, seismic structure and evolution of the Kaapvaal-Zimbabwe Craton, Science 297, 1683-1686.

Shirey, S. B., Carlson., R. W., Richardson, S. H., Menzies, A., Gurney, J. J., Pearson, D. G., Harris, J. W., and Wiechert, U. 2001. Archean emplacement of eclogitic components into the Lithospheric mantle during formation of the Kaapvaal craton, Geophys. Res. Lett. 28, 2509-2512

Smith, C.B. (1983) Pb, Sr and $\mathrm{Nd}$ isotopic evidence for sources of southern African Cretaceous kimberlites. Nature 304, 51-54.

Walker, R., Carlson, R., Shirey, S. and Boyd, F. (1989) Os, $\mathrm{Sr}, \mathrm{Nd}$, and $\mathrm{Pb}$ isotope systematics of southern African peridotite xenoliths: implications for the chemical evolution of subcontinental mantle. Geochimica et Cosmochimica Acta, 53, 1583-1595.

Contact: B P Garden, Geological Sciences, University of Cape Town, Rondebosch 7701, Cape Town South Africa, Email: bgarden@geology.uct.ac.za 